\title{
Melanogenuria in a case of haemochromatosis secondary to sideroblastic anaemia
}

\author{
E. R. MOXON \\ B.A., M.B., B.Chir., M.R.C.P.E.*
}

House Physician

\author{
C. Pike \\ M.D., F.C.Path. \\ Consultant Pathologist
}

\section{Peace Memorial Hospital, Watford, Herts}

IT IS now over 30 years since Sheldon's classical monograph on haemochromatosis, but in spite of much intensive research, many aspects of this condition remain enigmatic. We have recently observed a case of haemochromatosis secondary to sideroblastic anaemia in which the appearance of the clinical signs of haemochromatosis were unusually rapid and paralleled by a dramatic and fatal deterioration in the patient. In the later stages of the disease the patient became excessively pigmented and was observed to pass jet-black urine. Melanogens were identified by the laboratory. In a comprehensive review of the literature we found only six reports of melanogenuria occurring in the absence of melanotic sarcoma.

\section{Case report}

R.G., a 59-year-old lorry driver, was admitted to the Peace Memorial Hospital on 2 March 1967 with a history of having vomited half a pint of blood $2 \mathrm{hr}$ previously. He had been seen at the same hospital in January 1963 complaining of tiredness and was found to have the following blood count: haemoglobin, $9.4 \mathrm{~g} / 100 \mathrm{ml}$; red cell count, 5,760,000; colour index, 0.63 ; film, hypochromia with marked aniscocytosis and poikilocytosis. White series normal. There was at this time no evidence of blood loss and he was tried on firstly oral and then intramuscular iron, but with no response. By December 1964 his haemoglobin was $8.6 \mathrm{~g} / 100 \mathrm{ml}$; red cell count, 5,350,000; reticulocytes, $1 \%$; serum iron, $445 \mu \mathrm{g} /$ $100 \mathrm{ml}$. In view of the lack of response to iron, he was tried on pyridoxine (vitamin $\mathbf{B}_{6}$ ). A dose of $150 \mathrm{mg}$ was given intravenously and a course of oral treatment started $(100 \mathrm{mg}$ o.d.). On the 10th day his reticulocyte count rose to $3.2 \%$ and by January 1965 his haemoglobin was $12.6 \mathrm{~g} / 100 \mathrm{ml}$ rising to $13.8 \mathrm{~g} / 100 \mathrm{ml}$ in March 1965. At this time his red cell count was $6,000,000$ and the serum iron was $150 \mu \mathrm{g} /$ $100 \mathrm{ml}$.

The patient did not attend until January 1966

* Currently SHO Paediatrics, Hospital for Sick Children, Great Ormond Street, London, W.1. when he reappeared complaining of excessive fatigue and dyspnoea. His haemoglobin was $7 \cdot 2 \mathrm{~g} / 100 \mathrm{ml}$; red cell count, 4,700,000 and his serum iron was $376 \mu \mathrm{g} / 100 \mathrm{ml}$. The dose of pyridoxine was increased and his haemoglobin rose to $11.0 \mathrm{~g} / 100 \mathrm{ml}$ and the serum iron fell to $218 \mu \mathrm{g} / 100 \mathrm{ml}$. For the 6 months prior to admission his haemoglobin had averaged $10 \cdot 1 \mathrm{~g} / 100 \mathrm{ml}$.

On admission the patient gave a history of infective hepatitis in 1945 when he had been in bed for 3 months. His diet had been balanced, but his appetite poor for some weeks. He did not suffer from indigestion and had been teetotal all his life.

On examination the patient was sweating with peripheral vaso-constriction, pulse 96 , blood pressure $110 / 60 \mathrm{mmHg}$. The liver edge was felt two fingers below the costal margin, and a spleen tip was easily palpable. Spider naevi and palmar erythema were absent and the patient was not jaundiced. A provisional diagnosis of bleeding from oesophageal varices due to cirrhosis was made. $\mathrm{Hb}$ was $9 \cdot 1$ $\mathrm{g} / 100 \mathrm{ml}$ some $2 \mathrm{hr}$ after the haematemesis. By midafternoon the patient's condition had deteriorated, he vomited $800 \mathrm{ml}$ of fresh blood and his blood pressure became unrecordable. An emergency laparotomy was performed, at which an erosion which was responsible for the bleeding was detected half an inch below the oesophageal-gastric junction on the lesser curvature. The spleen was enlarged four times, a fine cirrhosis of the liver was noted. There were varices at the lower end of the oesophagus.

Post-operatively the patient became jaundiced and a flapping tremor could be elicited for the first 5 days. By the 10th day post-operatively ascites had developed and fluid was oozing freely through the wound. The prothrombin time was $17 \mathrm{sec}$, plasma proteins normal and barium swallow 4 weeks postoperatively confirmed oesophageal varices.

He was transferred to the medical ward for further investigation of his anaemia.

Investigations. At this time: $\mathrm{Hb} 9.9 \mathrm{~g} / 100 \mathrm{ml}$; film, slight aniscocytosis with marked hypochromia; ESR, $24 \mathrm{~mm} / \mathrm{hr}$ (Westergren), prothrombin time, 
$16 \mathrm{sec}$ (control $12 \mathrm{sec}$ ); bone marrow, 'blood clot containing marrow particles which were almost $100 \%$ cellular. Megakaryocytes within normal limits. Erythropoiesis is normoblastic and haemopoiesis normal. Sideroblasts present'. Bilirubin, $0.8 \mathrm{mg} /$ $100 \mathrm{ml}$; alkaline phosphatase, $11 \mathrm{KA}$ units; thymol turbidity 4 units; SGOT, 118 units; SGPT, 118 units; total proteins, $6.8 \mathrm{~g} / 100 \mathrm{ml}$, electrophoresis, raised $\gamma$-globulin. His haemoglobin rose to $12.3 \mathrm{~g} / 100 \mathrm{ml}$ on pyridoxine, and he was discharged on 4 May 1967 on diuretics, low protein and salt diet.

On 31 May 1967 the patient was seen at the followup clinic. His condition had deteriorated rapidly. The striking change was a diffuse dusky pigmentation, particularly marked around the laparotomy scar, but absent from the oral mucosa. His skin had a shiny quality and there was an obvious decrease in the quantity of hair on his scalp, in his axillae, around his genitalia and very strikingly, from the shins of both legs. Both testes were atrophied and gynaecomastia was present. The rapidity with which these signs had appeared can hardly be over-stressed, especially the degree of pigmentation. (They were not present at the time of laparotomy in March.) There were no spider naevi nor did he have palmar erythema. His sclerae were icteric and he was clinically anaemic. There was mild cheilosis, and his tongue was depapillated but not sore.

It was immediately clear that the patient was mentally and physically slow, and he was unsteady on his feet. Measured weight loss was $12 \mathrm{lb}$ since discharge. BP 110/60. Flap tremor was elicited. Liver and spleen remained enlarged to the same degree as found in March.

The patient was re-admitted, investigations at this time showing: $\mathrm{Hb}, 7 \cdot 2 \mathrm{~g} / 100 \mathrm{ml}$; RBC, 3,000,000; $\mathrm{PCV}, 21 \%$; MCHC, $30 \%$; reticulocytes, $2 \%$; serum iron, $600 \mu \mathrm{g} / 100 \mathrm{ml}$; serum folate, $2 \mathrm{~m} \mu \mathrm{g} / 100 \mathrm{ml}$; serum $B_{1:}, 390 \mathrm{pg} / 100 \mathrm{ml}$; direct Coombs' test, -ve; total iron binding capacity, $155 \mu \mathrm{g} / 100 \mathrm{ml}$; plasma sodium, $126 \mathrm{mEq} / 1$; potassium, $4 \cdot 1 \mathrm{mEq} / \mathrm{l}$; chloride, $90 \mathrm{mEq} / \mathrm{l}$; carbonate, $28 \mathrm{mEq} / 1$; urea, $63 \mathrm{mg} / 100 \mathrm{ml}$; bilirubin, $1.1 \mathrm{mg} / 100 \mathrm{ml}$; alkaline phosphatase, 11 KA units; thymol turbidity, 1; SGOT, 54; SGPT, 151 units; prothrombin time, $20 \mathrm{sec}$ (control $12 \mathrm{sec}$ ); total proteins, $6.8 \mathrm{~g} / 100 \mathrm{ml}$; albumen within normal limits; raised $\gamma$-globulin; occult bloods, negative on three occasions; plasma cortisol, $40 \mu \mathrm{g} /$ $100 \mathrm{ml}(09 \cdot 00 \mathrm{hr})$. Skin biopsy, abundant melanin. Scanty haemosiderin present in one sweat gland.

On 15 June 1967 a specimen of his urine was observed to have developed a jet-black discolouration. On two occasions a positive Thormählen reaction for melanogens was obtained on testing freshly voided urine.

The patient's condition continued to deteriorate and there was an extraordinary increase in the degree of melanin pigmentation, the area around his laparotomy scar becoming dark brown. The blood sugar was abnormal for the first time on the 12 July 1967 , values of 180 and $160 \mathrm{mg} / 100 \mathrm{ml}$ being obtained at $12.00 \mathrm{hr}$ and $16.00 \mathrm{hr}$, respectively. He died on the 19 July 1967.

\section{Necropsy}

Relevant positive findings were:

External appearances. Adjacent to the abdominal scar the skin shows dark brown pigmentation.

Digestive system. In the stomach there are several small, superficial erosions. The liver is enlarged and weighs $1540.0 \mathrm{~g}$. It is firm, rust-coloured and finely nodular. The dilated gall bladder contains viscid bile. The pancreas is swollen, firm and deep brown.

Haemopoietic and endocrine systems. Spinal bonemarrow is red. The tracheo-bronchial and abdominal lymph nodes are enlarged and deep brown. The spleen is enlarged and weighs $530.0 \mathrm{~g}$, its cut surface being rust-coloured. The thyroid, suprarenals and pituitary appear normal.

\section{Histology}

Myocardium. There is slight patchy fibrosis. Most cardiac muscle fibres contain haemosiderin. Stomach. Superficial erosions are present. Haemosiderin in all coats, but maximal in epithelial cells. Liver. Multilobular cirrhosis with marked proliferation of bile ducts and fatty change in hepatic cells. Large amounts of haemosiderin are present in hepatic cells, Küpffer cells and bile duct epithelium. Pancreas. There is fibrosis and some fat replacement. Islets clearly recognizable, some showing hyaline degeneration. Haemosiderin present in glandular and islet cells. Lymph nodes. Very heavy deposition of haemosiderin, maximal in the cortex. Spleen. There is patchy fibrosis and lymphoid follicles are reduced in size. There is a moderate amount of haemosiderin, maximal in the capsule, trabeculae and the walls of the larger vessels. Suprarenals. There is a heavy deposition of haemosiderin in the outer cells of the cortex. Pituitary. Haemosiderin concentrated in pars intermedia, a little also in the pars anterior. Kidney. Haemosiderin is present in large amounts in the tubules of the cortex. Skin. There is increased melanin in the epidermis. Haemosiderin is present in cells of the superficial corium and is concentrated around sweat glands of the deeper corium.

\section{Discussion}

From the haematological data, in particular the bone-marrow and response to pyridoxine, we conclude that this was a case of haemachromatosis secondary to sideroblastic anaemia.

There are now several well discussed cases of 
refractory anaemia (Caroli et al., 1957; Dacie et al., 1959; Heilmeyer, 1967) in which the defect in incorporation of iron into haemoglobin leads to hyperferricaemia and haemachromatosis ensues, the pattern and distribution of which histologically is indistinguishable from primary haemachromatosis.

The patient received several months' iron therapy in 1963. A total of 14 pints of blood transfused in 1967 would be only a minimal contribution to the total iron deposits found at necropsy.

Serum folate was low $(2 \mathrm{ng} / 100 \mathrm{ml})$ and this can be associated with increased absorption of iron from the gastro-intestinal tract.

Great interest centred around the finding of melanogenuria. At a clinical level there was gross pathological pigmentation and the patient's urine was observed to become jet-black in colour some hours after voiding. A positive Thormählen reaction (1887) was obtained on two occasions and ferric chloride tests were also positive. Despite isolated reports of melanogenuria occurring in conditions other than melanotic sarcoma, it is a very rare phenomenon (Weiss, 1922; Peters, 1923; Haden \& Orr, 1924; Risak, 1931; Ludwig, 1954; Turner Bynum, 1957).

Melanogens are colourless derivatives of tyrosine which will spontaneously oxidize to melanin. Thus, clinically, their presence is suspected if voided urine is observed to darken on exposure to atmospheric oxygen, developing a very dark-brown to jet-black discolouration. Such a phenomenon is characteristic of homogentisic acid, melanogens or melanin and has also been reported on patients receiving injections of iron-sorbitol-citric acid (Jectofer).

For over a century melanogenuria has been known to be associated with the presence of melanotic sarcoma. Previous reports of melanogenuria occurring in the absence of melanotic sarcoma must be viewed with some caution owing to the poor specificity of tests employed to detect melanogens.

Failure to differentiate between melanuria and melanogenuria in addition to ignorance as to their biochemical nature existed until Leonhardi (1954) demonstrated by chromatography the existence of two classes of melanogens, the indole-melanogens (IMG) and the phenol-melanogens (PMG). Duchon $\&$ Pechan (1963) have confirmed and expanded these findings.

It is significant that since 1954 reports of melanogens in the absence of melanotic sarcoma are conspicuous by their absence, although Cantarow \& Trumper (1962) state that it may occur in a wide variety of conditions.

The basis of detection of melanogens is the use of the Thormählen reaction. Various oxidation tests (using reagents such as ferric chloride or alkaline copper sulphate) and Ehrlich's aldehyde reagent are also in current use. Of these tests, only the Thormählen reaction exhibits any acceptable degree of specificity for melanogens. However, even the Thormählen reaction may give confusing results in the presence of ascorbic acid, thiamine or its metabolites and creatinine (Duchon \& Pechan, 1963). Melanin and PMG give a negative Thormählen reaction. Thus, although the Thormählen reaction is useful as a screening test for melanogens, precise identification must ultimately depend on chromatography. A simultaneous positive with the Thormählen reaction and a ferric chloride test is extremely suggestive of melanogenuria.

Fitzpatrick (personal communication) in his extensive experience has only seen melanogenuria in association with melanotic sarcoma and hepatic metastases. The very rapid development of pigmentation which is an unusual feature of haemachromatosis suggests some unusual disturbance of pigment control in this case and it would seem on theoretical grounds to be a situation in which melanogenuria might reasonably be expected. Ludwig (1957) has considered the possibility of iron deposits in liver, resulting in abnormal catabolism of tyrosine, producing melanogens.

\section{References}

Cantarow, A. \& Trumper, M. (1962) Clinical Biochemistry, 6th edn, p. 184. Saunders, Philadelphia.

Caroli, J., Bernard, J., Bessis, M., Combrisson, A., Maladssent, R. \& Breton, J. (1957) Hémachromatose avec anémie hypochrome et absence d'hémoglobine anormale étude au microscope electronique. Presse Médicale, 65, 1991.

Dacie, J., Smith, M.D., White, J.C. \& Mollin, D.L. (1959) Refractory normoblastic anaemia; a clinical and haematological study of seven cases. British Journal of Haemato$\log y, 5,56$.

Duchon, J. \& Pechan, Z. (1963) The biochemical and clinical significance of melanogenuria. Annals of the New York Academy of Sciences, 100, 1048.

Fitzpatrick, T.B., Becker, S.W., Lerner, A.B. \& MontGOMERY, H. (1950) Tyrosinase in human skin; demonstration of its presence and its role in melanin formation. Science, 112, 223.

HADEN, R.L. \& ORR, T.G. (1924) Melanuria in the absence of melanotic tumour. Bulletin of the Johns Hopkins Hospital, 35, 58.

Hellmeyer, L. (1967) Pathogenesis of haemochromatosis. Medicine, 46, 209.

LeONHARDI, G. (1954) Papier chromatographische Trennung von Harnmelanogen. Naturwissenschaften, 41, 141.

LudwIG, G.D. (1954) Melanuria. Journal of Clinical Investigation, 33,954 .

Peters, J.P. (1963) Melanuria without melanosarcoma. Archives of Internal Medicine, 32, 709.

RisAK, E. (1931) Zur Fragedes Auftretens von Melanogen im Urin normaler Individuen nach Sonnenbestrählung. Erwiderung auf die Arbeit von Jui-Wu-Mu. Klinische Wochenschrift, 10, 986. 